\title{
PENYULUHAN DAN PENDAMPINGAN PENGGUNAAN PUPUK ORGANIK ECO FARMING PADA KELOMPOK TANI SINAR HARAPAN DUSUN PAOK KAMBUT DESATELAGAWARU KECAMATAN LABUAPI
}

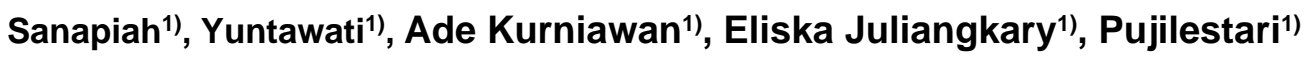 \\ 1)Pendidikan Matematika, FSTT, Universitas Pendidikan Mandalika, Mataram, NTB, Indonesia \\ Corresponding author : Sanapiah \\ E-mail : sanapiah@undikma.ac.id
}

Diterima 17 November 2021, Direvisi 02 Desember 2021, Disetujui 02 Desember 2021

\begin{abstract}
ABSTRAK
Kelompok Tani Sinar Harapan adalah kelompok tani di Dusun Paok Kambut Desa Telagawaru Kecamatan Labuapi Kabupaten Lombok Barat yang fokus membudidayakan jagung manis pada setiap musim tanam tanpa dijeda dengan tanaman lainnya. Kelompok tani ini termasuk salah satu daerah produksi jagung manis untuk mensuplay kebutuhan pedagang- pedagang sayur di lokal dan regional Kota Mataram dan Lombok Barat, termasuk untuk para penjual jagung manis keliling. Namun ditengah wabah pandemic Covid-19, kelompok tani jagung manis ini dan juga kelompok-kelompok tani lainnya di berbagai daerah mengalami permasalahan yang sama terkait dengan pupuk subsidi yang langka dan sulit di dapatkan. Adapun solusi yang ditawarkan untuk mengatasi permasalahan yang dihadapi oleh Kelompok Tani Insan Harapan adalah 1) memberikan penyuluhan kepada anggota kelompok tani untuk mulai beralih ke pupuk organik Eco Farming yang kualitasnya sudah teruji dan harganya juga terjangkau sebagai upaya membuka wawasan para petani yang selama ini selalu tergantung pada pupuk Kimia, dan 2) melakukan pendampingan kepada anggota kelompok tani Sinar Harapan dalam pengaplikasian Pupuk Eco Farming untuk memberikan keyakinan akan manfaat dan kualitas dari pupuk organic eco farming. Metode Kegiatan pengabdian ini dilakukan dengan grup Focus Diskusi (FGD) yang diaplikasikan dalam kegiatan Penyuluhan dan pendampingan. Data hasil pengabdian diperoleh dari hasil wawancara dan pengamatan langsung. Dari hasil kegiatan pengabdian ini dapat disimpulkan bahwa terdapat peningkatan hasil panen jagung manis sekitar $20 \%$ dengan pengurangan Pukim hingga $80 \%$ setelah musim tanam kedua sampai ke empat (4 kali musim tanam) dan meningkatkan keterampilan anggota kelompok tani Sinar Harapan dalam pengaplikasian Pupuk Organik Eco Farming dengan tanpa pendampingan.
\end{abstract}

Kata kunci: pendampingan; pupuk organic; eco farming; kelompok tani.

\begin{abstract}
Sinar Harapan Farmers Group is a farmer group in Paok Kambut Hamlet, Telagawaru Village, Labuapi District, West Lombok Regency that focuses on cultivating sweet corn in each growing season without being paused with other crops. This farmer group is one of the sweet corn production areas to supply the needs of local and regional vegetable traders in Mataram and West Lombok, including itinerant sweet corn sellers. However, in the midst of the Covid-19 pandemic, this sweet corn farmer group as well as other farmer groups in various regions experienced the same problem related to subsidized fertilizers which were scarce and difficult to obtain. The solutions offered to overcome the problems faced by the Insan Harapan Farmer Group are 1) providing counseling to members of the farmer group to start switching to Eco Farming organic fertilizers whose quality has been tested and the price is also affordable as an effort to open the horizons of the farmers who have always depended on them. on chemical fertilizers, and 2) providing assistance to members of the Sinar Harapan farmer group in the application of Eco Farming Fertilizers to provide confidence in the benefits and quality of organic eco farming fertilizers. Methods This service activity is carried out with Focus Discussion groups (FGD) which are applied in counseling and mentoring activities. The data from the service was obtained from the results of interviews and direct observations. From the results of this service activity, it can be concluded that there is an increase in sweet corn yields of about $20 \%$ with a Pukim reduction of up to $80 \%$ after the second to fourth growing season (4 planting seasons) and improving the skills of members of the Sinar Harapan farmer group in the application of Eco Farming Organic Fertilizers. with no assistance.
\end{abstract}

Keywords: assistance; organic fertilizer; eco farming; farmer groups. 


\section{PENDAHULUAN}

Kelompok

tani merupakan perkumpulan yang beranggotakan para petani di wilayah desa, tidak selalu semua petani di desa tersebut bergabung pada kegiatan seperti ini. Kelompok tani mempunyai peranan yang sangat penting dalam kehidupan masyarakat tani, sebab segala kegiatan dan permasalahan dalam berusaha tani dilaksanakan oleh kelompok secara bersamaan. Dengan adanya kelompok tani, para petani dapat bersamasama memecahkan permasalahan yang antara lain berupa pemenuhan sarana produksi pertanian, masalah teknis produksi dan pemasaran hasil. Menurut Handayani et al., (2019) bahwa peningkatan produktivitas dalam sektor pertanian dapat diwujudkan dengan cara membentuk kelompok-kelompok tani di pedesaan.

Kelompok Tani Sinar Harapan adalah salah satu kelompok tani yang ada di Dusun Paok Kambut Desa Telagawaru Kecamatan Labuapi Kabupaten Lombok Barat yang fokus membudidayakan jagung manis pada setiap musim tanam tanpa dijeda dengan tanaman lainnya. Keberadaan kelompok petani budidaya jagung manis ini menjadi sentral untuk memenuhi kebutuhan konsumsi jagung untuk pasar lokal dan regional. Kelompok tani ini termasuk salah satu daerah produksi jagung manis untuk mensuplay kebutuhan pedagangpedagang sayur di lokal dan regional Kota Mataram dan Lombok Barat, termasuk untuk para penjual jagung manis keliling. Namun ditengah wabah pandemic Covid-19, kelompok tani jagung manis ini dan juga kelompokkelompok tani lainnya di berbagai daerah mengalami permasalahan yang sama terkait dengan pupuk subsidi yang langka dan sulit didapatkan. Kelangkaan pupuk subsidi ini dikarenakan pemerintah Indonesia harus mulai memangkas anggaran subsidi pupuk dan mengalihkannya ke program-program lain terkait investasi di teknologi pertanian (Adiraputra \& Supyandi, 2021).

Selain itu, petani tidak akan dapat memperoleh bagian untuk pupuk subsidi jika tidak memiliki kartu anggota kelompok tani di daerahnya. Ditambah lagi proses untuk mendapatkan pupuk subsidi harus memenuhi berbagai persyaratan. Dalam pembangunan pertanian, pupuk adalah unsur penting dan strategis untuk meningkatkan produktivitas dan menjadi bagian yang tidak dapat dipisahkan dari sistem usaha tani (Adiraputra \& Supyandi, 2021).

Kelangkaan pupuk subsidi ini sangat dirasakan oleh kelompok petani jagung ini dalam kurun waktu hampir 3 kali musim panen, sehingga keuntungan yang diperoleh semakin menurun akibat harus mencari dan menggunakan pupuk non subsidi yang harganya hingga $100 \%$ lebih mahal dari harga pupuk subsidi. Harga pupuk subsidi untuk $50 \mathrm{~kg}$ sebesar Rp 125.000, sedangkan harga pupuk non subsidi hingga mencapai harga sebesar Rp 300.000. Namun tidak ada jalan keluar bagi petani selain harus membeli pupuk non subsidi dengan harga sangat mahal. Kelangkaan pupuk dan tingginya biaya budi daya jagung manis ini tidak di dukungoleh tingginya harga jual jagung ketika panen. Tentu hal ini membuat para petani jagung khawatir dan mulai mencari alternatif untuk mengurai biaya pupuk yang semakin tinggi dan langka.

Salah satu alternatif yang bisa ditawarkan ke kelompok tani Sinar Harapan adalah memberikan penyuluhan untuk mulai mengajak petani beralih menggunakan pupuk organik dalam upaya mengurai ketergantungan petani selama ini terhadap pupuk anorganik. Penyuluhan pertanian berfungsi untuk memberikan pelayanan informasi dan Pendidikan yang dibutuhkan petani, sehingga petani dapat lebih baik dalam berusaha tani (Rahmawati et al., 2015). Kegiatan penyuluhan ini sangat tepat dilakukan di tengah kebingungan petani jagung manis mencari solusi akan pupuk yang langka. Namun permasalahannya tidak mudah memberikan keyakinan pada anggota kelompok tani untuk beralih ke pupuk organik dan meninggalkan penggunaan pupuk anorganik yang sudah menjadi kebiasaan petani selama ini. Oleh karena itu, sangat perlu dilakukan pendampingan penggunaan pupuk organik setelah melakukan penyuluhan awal. Salah satu pupuk organik yang dapat dilakukan penyuluhan dan pendampingan kepada kelompok tani ini adalah Eco Farming.

Eco Farming adalah pupuk organik super aktif hasil penelitian ahli pertanian IPB lebih dari 8 tahun dan telah teruji dan terbukti Eco Farming mampu mengembalikan kesuburan tanah, menjadikan tanaman sehat, produktif dan ramah lingkungan. Formula Eco Farming, memiliki nutrisi lengkap untuk kebutuhan tanaman dan bakteri positif (Decomposer) untuk restorasi kesuburan tanah sehingga mendekati syarat Agroekosistem Ideal (Ma'munir. 2020).

Eco Farming adalah pupuk atau nutrisi berbahan organik super aktif yang sudah mengandung unsur hara lengkap sesuai kebutuhan tanaman juga dilengkapi dengan bakteri positif yang akan menjadi biokatalisator dalam proses memperbaiki sifat fisik, biologi dan kimia dalam rangka mengembalikan kesuburan tanah. Selain itu, Eco Farming menggabungkan pupuk organik dan pupuk 
hayati yang mengembangbiakkan mikroorganisme positif untuk menyuburkan tanah.

Eco Farming di kemas dalam bentuk bricket ukuran 30 gram. Walaupun ukurannya kecil, tetapi daya keberkesanannya mampu mengcover lahan 1 hektar sebanding dengan 1 ton pupuk organik dari kotoran ternak. Namun jika dipadukan pemakaiannya dengan pupuk kimia,Eco Farming dapat menekan kebutuhan pupuk lainnya sampai $25 \%$, bahkan $0 \%$ sehingga bisa menjadi alternatif pengembangan produksi pertanian sehat ramah lingkungan menjadi lebih praktis, efektif, efisien dan ekonomis. Pemberdayaan pupuk organik (Eco Farming) pada tanah sangat penting dilakukan untuk meningkatkan efisiensi pengolahan tanah dan produksi tanaman yang berkelanjutan ((Iswahyudi et al., 2019).

$$
\text { Beberapa penelitian tentang }
$$

penggunaan Eco Farming telah dilakukan dan membawa dampak yang cukup poitif. Iswahyudi et al (2019) memaparkan hasil diseminasi teknologi di lapangan yang telah dilaksanakan sebagai berikut : (1) kelompok tani "Palem " sangat antusias dan menguasai aplikasi teknologi pupuk organik (eco farming), (2) peningkatan produksi padi mencapai $80 \%$, (3) pupuk organik ini dapat menghemat pupuk $\mathrm{N}$ (urea) mencapai $75 \%$, dan (4) petani sudah menguasai penggunaan pupuk organik (eco Farming) di lahan. Andriyani et al (2020) juga memaparkan hasil penelitian yang cukup menggembirakan tentang penggunaan pupuk organik eco farming di lahan percobaan yang menunjukkan peningkatan output produksi tanpa merusak lingkungan dan tidak merusak kesehatan.

Bagi para petani yang awam soal organik dan organisme tentu kurang faham akan manfaat organik dan mikroorganisme positif, mereka hanya mengetahui pupuk kimia saja dengan logika yang terbangun sejak awal bahwa lahan sekian meter memerlukan sekian kilo, sekian kwintal dan sekian ton. Eco Farming hadir untuk solusi kepada para Petani untuk menyuburkan tanah dengan melalui bantuan kerja aktif mikroorganisme yang terdapat dalam Eco Farming dalam tanah, berbeda dengan konsep kimia yang membunuh mikroorganisme positif dalam tanah sehingga cacing tanahpun ikut berkurang yang mengakibatkan kurang suburnya tanah. Tanah yang kurang subur tentu yang rugi pemilik tanahnya, petaninya. Tanah yang subur tentu menjadikan tanaman tumbuh lebih sehat, kuat serta produktif. Masa pembuahan dan masa panen lebih cepat jika dibandingkan dengan tanaman yang menggunakan pupuk kimia.

\section{METODE}

Kegiatan pengabdian masyarakat ini dilaksanakan di Dusun Paok Kambut Desa Telagawaru Kecamatan Labuapi Kabupaten Lombok Barat. Hanya digunakan 1 orang mitra yang didampingi secara langsung dalam proses pengaplikasian eco farming untuk lahan 10 are dengan diberikan 1 tube eco farming secara gratis untuk 1 kali musim tanam. Metode pelaksanaan kegiatan dengan FGD (Fokus Group Diskusi) yang dilaksanakan mulai bulan Mei-November 2021. Adapun pelaksanan kegiatan FGD pada kelompok tani Sinar Harapan untuk memberikan keyakinan dan membantu mulai beralih ke pupuk organik Eco Farming dilakukan dengan langkah-langkah sebagi berikut:

1. Penyuluhan

a. Terlebih dahulu melakukan koordinasi dengan ketua kelompok tani terkait dengan waktu pelaksanaan kegiatan penyuluhan. Mengiat para anggota kelompok tani memiliki kesibukan di lahan/sawah masing-masing.

b. Menetapkan materi penyuluhan yang berkaitan dengan 1) Perbedaan pupuk organik dan anorganik serta dampak bagi kesehatan manusia dan tanaman, 2) Apa itu pupuk organik Eco Farming, cara memperoleh pupuk organic Eco Farming, cara kerja serta cara penggunaan pupuk Organik Eco Farming.

c. Kegitan penyuluhan dilaksanakan kurang lebih 2 kali untuk memberikan banyak pengetahuan bagi para anggota kelompok tani tentang Pupuk Organik Eco Farming.

2. Pendampingan

a. Menetapkan lahan demplot dengan luasan 10 are

b. Mengecek Ph lahan demplot dengan alat uji.

c. Melakukan pengolahan tanah untuk proses aplikasi pertama yang di fokuskan ke lahanatau tanah tanpa tanaman.

d. Kegiatan pendampingan pembuatan biang Pupuk Eco Farming yang di fermentasi selama 3 hari, semakain lama dilakaun fermentasi, maka biang pupuk eco farming sangat bagus untuk pengaplikan perdana yang ini dilakukan 5 hari sebelum jagung di tanam.

e. Pendampingan pembuatan biang Eco Farming pada pengaplikasian kedua setelah jagung berusia 10 hari setelah tanam, pengaplikasian ketiga pada usia jagung 20 hari setelah tanam dan terakhir pengaplikasian keempat pada jagung 
usia 30 hari setelah tanam. Pada pembuatan biang eco farming pada aplikasi kedua sampai keempat tidak dilakukan fermentasi. Tetapi dilakukan pembuatan biang hanya dalam waktu 15-30 menit sebelum dilakukan aplikasi khusus untuk tanaman.

\section{Pengamatan}

Kegiatan pengamatan dilakukan untuk memantau pertumbuhan tanaman jagung dengan melihat pertumbuhan tiap minggu serta melakukan pengecekan $\mathrm{Ph}$ tanah setelah menggunakan pupuk organic eco farming. Pengamatan yang dilakukan, yaitu mengukur tinggi tanaman $(\mathrm{cm})$, diameter batang $(\mathrm{cm})$ dan jumlah daun (helai) yang diamati setiap interval 2 minggu. Pengamatan pertumbuhan tinggi dilakukan dengan mengukur tinggi tanaman dari permukaan tanah sampai ujung daun tertinggi. Pengamatan pertumbuhan jumlah daun dilakukan secara manual dengan menghitung helai daun dari daun pertama (bagian atas) sampai daun terakhir (bagian bawah). Pengamatan diameter batang dilakukan secara manual, yaitu dengan mengukur batang tanaman secara melintang dengan menggunakan jangka sorong.

Bagan Alur kegiatan Pengabdian selengkapnya diperlihatkan pada gambar 1 berikut.

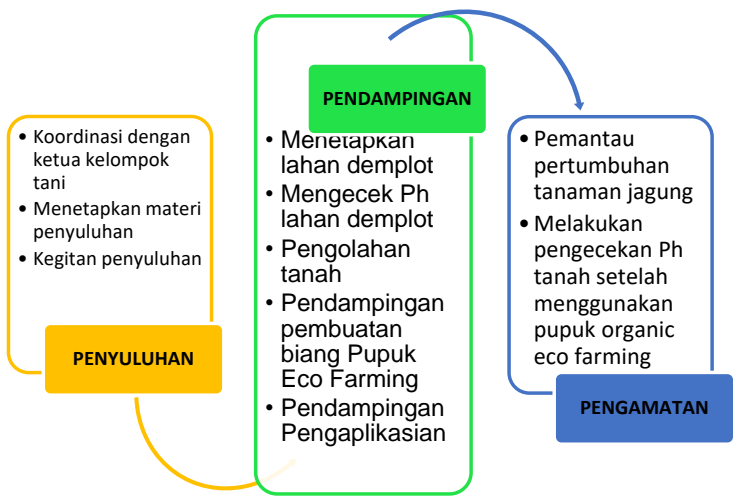

Gambar 1. Bagan Alur kegiatan pengabdian

\section{HASIL DAN PEMBAHASAN \\ Kegiatan Penyuluhan/FGD 1}

Kegiatan pengabdian kepada masyarakat ini dilaksanakan di Dusun Paok Kambut Desa Telagawaru Kecamatan Labuapi Kabupaten Lombok Barat pada kelompok Kelompok Tani Sinar Harapan. Tahap awal kegiatan pengabdian ini dilakukan dengan mengadakan kegiatan penyuluhan/FGD 1 terhadap anggota kelompok tani (Dapat dilihat pada Gambar 2). Dalam pelaksanaan kegiatan penyuluhan ini, tidak banyak dihadiri oleh anggota kelompok tani jagung manis dari dusun Paok Kambut, melainkan banyak dihadiri oleh berbagai anggota kelompok tani lain bahkan pengusaha pupuk dan pengusaha dibidang pertanian yang berasal dari kota mataram dan Lombok Barat dan sekitarnya. Karena kegiatan penyuluhan ini dilaksakan bersifat terbuka untuk para masyarakat luas untuk memberikan wawasan tentang pupuk organik, khususnya eco farming.

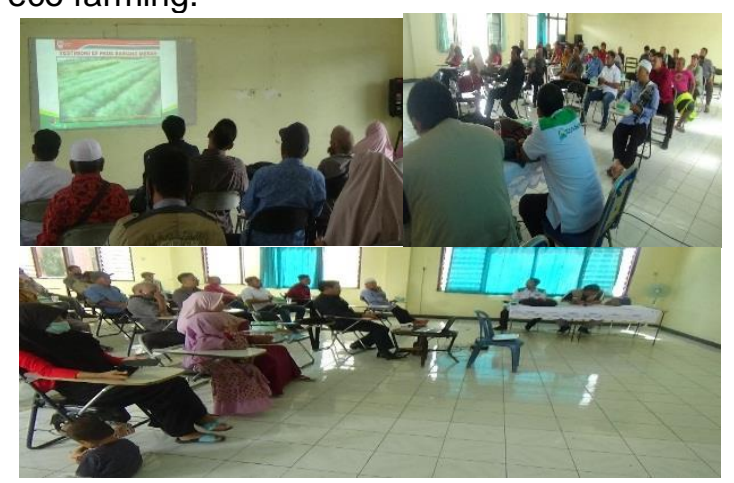

Gambar 2. Pelaksanaan Kegiatan Peyuluhan Pupuk Organik Eco Farming.

Dari antusias yang ditunjukkan oleh peserta kegiatan penyuluhan, menunjukkan bahwa para peserta mempunyai keterbuakan dan keinginan yang positif dalam mencoba mulai beralih ke penggunaan pupuk organik eco farming ditengah kelangkaan pupuk anorganik subsidi.

Kegiatan penyuluhan yang direncanakan akan dilaksanakan 2 kali, namun hanya dapat dilaksanakan 1 kali. Adapun materi penyuluhan yang diberikan antara lain 1) menjelasakan perbedaan pupuk organik dan anorganik serta dampak bagi kesehatan manusia dan tanaman, 2) Apa itu pupuk organik Eco Farming, cara memperoleh pupuk organic Eco Farming, cara kerja serta cara penggunaan pupuk Organik Eco Farming, 3) Menyajian berbagai video testimony penggunaan pupuk organic eco farming pada berbagai jenis tanaman dan lokasi yang berbeda-beda.

\section{Kegiatan Pendampingan dan Pengamatan \\ Setelah kegiatan penyuluhan} dilaksanakan, anggota tim melakukan koordinasi awal dengan salah seorang anggota kelompok tani Sinar Harapan yang akan segera melakukan penanaman jagung manis pada luas lahan 10 are ( Dapat dilihat pada gambar 3). Dari hasil koordinasi awal, didapatkan informasi bahwa petani jagung manis tersebut tidak melakukan pengolahan tanah terlebih dahulu. Artinya tanah bekas penanaman jagung manis sebelumnya tidak diolah/dibajak. Namun langsung ditanam kembali di sekitar pohon bekas tanaman sebelumnya. Sehingga pengaplikasian pupuk organic eco farming 
tahap awal yang difokuskan pada tanah sebelum tanam tidak dapat dilakukan. Dengan demikian, maka pengaplikasian pupuk organik eco farming pertama akan dilakukan pada 10 hari tanam jagung setelah tanam.

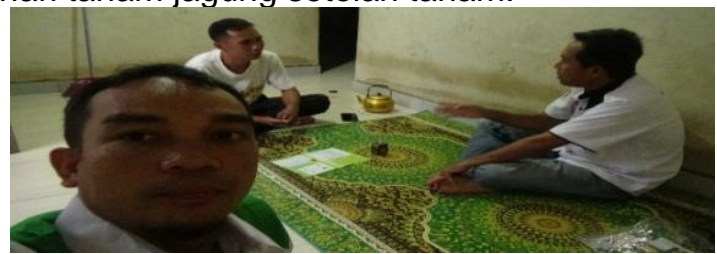

Gambar 3. Koordinasi awal dengan ketua dan salah seorang angota kelompok.

Perlu diketahui bahwa pengaplikasian pupuk organik eco farming pada tanaman jagung dilakukan dengan cara di semprot pada waktu 7 hari sebelum tanam di media tanah, dan pengaplikasian pada tanaman jagung dilakukan tiap 10 hari setelah tanam (hst) sebanyak 3 kali pengaplikasian (10 hst, 20 hst, dan 30 hst).

Selanjutnya, setelah jagung berumur 10 hari setelah tanam dilakukan pengaplikasian pertama pada tanaman dengan jumlah daun 3 helai (Dapat dilihat pada gambar 4). Namun sebelum itu, petani jagung didampingi dalam proses pencampuran biang eco farming. Setidaknya, biang dari eco farming yang sudah dibuat didiamkan kurang lebih 15 menit sebelum pengaplikasian.

Untuk lahan 10 are, digunakan $100 \mathrm{ml}$ biang eco farming yang di campurkan ke dalam 2 tong semprot. Tiap tong semprot dibutuhkan $50 \mathrm{ml}$ biang eco farming yang kemudian dicampurkan dengan air sampai penuh dalam tong semprot ukuran $15-17 \mathrm{ml}$.

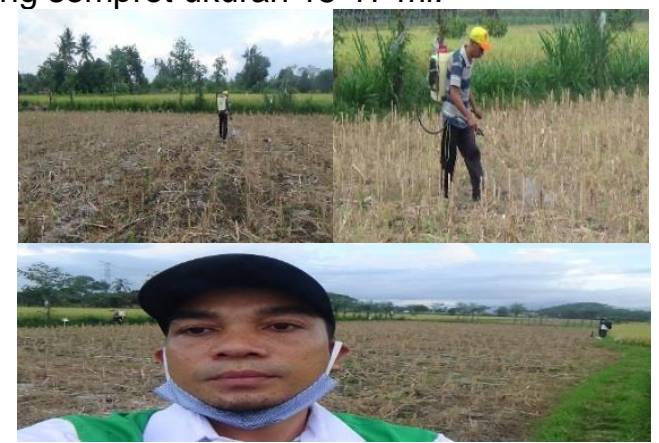

Gambar 4. Pengaplikasian eco farming $10 \mathrm{hst}$

Pada kegiatan pendampingan petani jagung manis di lokasi ini. Dosis penggunaan eco farming pada umur 10 hst ditambah yang sesuai anjuran hanya $50 \mathrm{ml}$ biang eco farming untuk 1 tong semprot, diubah menjadi $100 \mathrm{ml}$ untuk 1 tong. Perubahan ini dilakukan, karena pengaplikasian eco farming pada tanah tidak dilakukan sebelumnya. Namun perlu diketahui, bahwa kelebihan dosis penggunaan eco farming pada tanaman tidak memberikan pengaruh negatif. Namun justru sebaliknya. Hanya saya perlu penggunaan dosis sesuai anjuran yang telah di tetapkan di kemasan produk.

Tim pengabdian melakukan kunjungan ke lahan demplot pada usia 16 hst atau 6 hari setelah pengalikasian pertama (Dapat dilihat pada gambar 5). Nampak bahwa pertumbuhan jagung cukup baik dengan jumlah daun sekitar 4-5 helai tiap pohon.

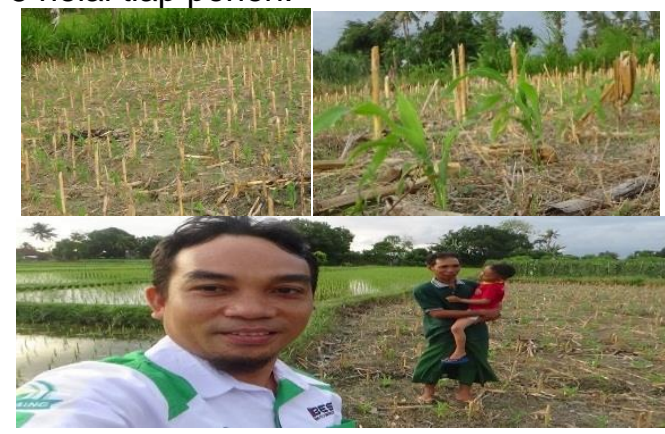

Gambar 5. Kunjungan lahan Demplot eco farming umur 16 hst.

Pada pengaplikasian kedua umur 20 hst, tim pengabdian tidak dapat mendamping secara langsung proses pengaplikasian. Namun untuk proses pembuatan biang eco farming pada pengaplikasian kedua dibimbing melalui media telpon dan pemilik lahan juga menggukan tambahan pupuk urea pada usia jagung 15 hst atau jeda 5 hari setelah pengaplikasian eco farming. Setelah usia jagung manis 25 hst, tim pengabdian melakukan pemantauan perkembangan jagung (Dapat dilihat pada gambar 6). Nampak jagung manis tumbuh secara subur dan perkembangan tumbuh secara merata. Daun jagung manis berkisar antara 6-8 helai dengan diameter batang sekitar $4-5 \mathrm{~cm}$.

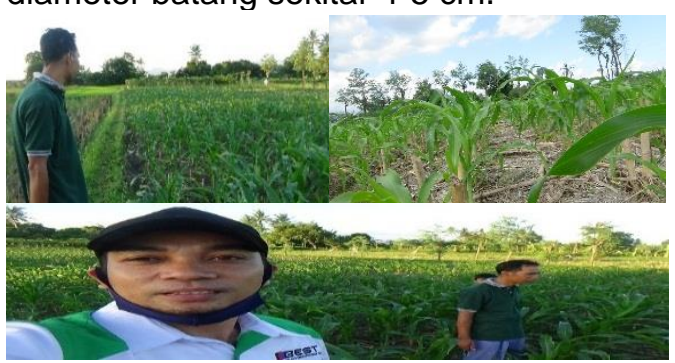

Gambar 6. Kunjungan lahan Demplot eco farming umur $25 \mathrm{hst}$.

Adapun bibit jagung manis yang dipakai pada lahan demplot ini yaitu jagung manis Hibrida F1 dengan Kopmentan no.1934/Kpts/SR.I20/5/2021 dari PT. Agri Makmur Pertiwi Bandung (Dapat dilihat pada gambar 7). Dikatakan oleh pak Muzakir pemilik lahan demplot ini, bahwa jenis bibit jagung manis ini yang paling murah dibandingkan dengan jenis jagung lainnya. Walaupun 
demikian, beliau mengatakan bahwa pertumbuhan jagung dari bibit ini tidak kalah bagus dengan bibit yang harga nya lebih mahal berkat menggunakan pupuk organic super aktif eco farming.
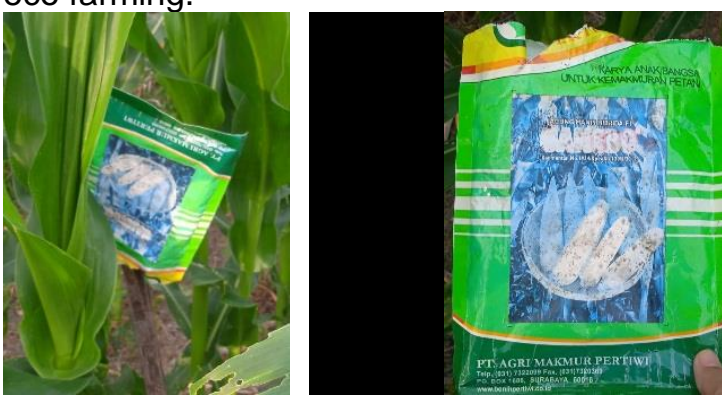

Gambar 7. Kemasan Bibit jagung manis Hibrida F1

Setelah pengaplikasian eco farming tahap ketiga umur 30 hst, pertumbuhan jangan sangat memuaskan pemilik lahan demplot jagung manis ini. Dari proses pengukuran yang dilakukan oleh tim pengabdian diperoleh data tinggi jagung yang sudah berumur 40 hari yang belum keluar buang sekitar 1,50-1,65 cm dengan diameter batang rata-rata $7-8 \mathrm{~cm}$ dan lebar daun sekitar $7 \mathrm{~cm}$ (Dapat dilihat pada gambar 8). Sedangkan untuk jagung yang sudah berbunga memiliki tinggi 1,70-1,92 cm dengan diameter batang 8-9 $\mathrm{cm}$ dan lebar daun sekitar 8-10 cm dengan jumlah daun tiap pohon 12-13 helai.
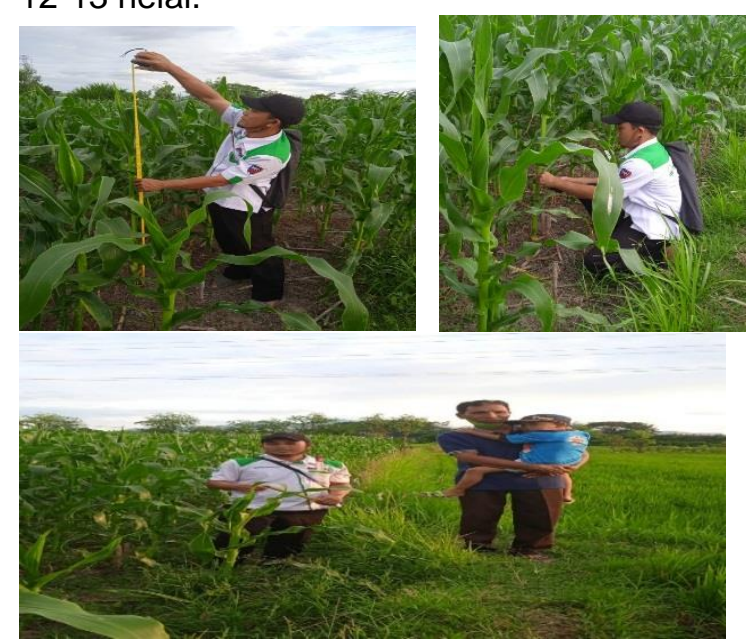

Gambar 8. Pengumpulan data pertumbuhan jagung setelah usia diatas 40 hst

Pemilik lahan jagung manis mempunyai keyakinan yang kuat bahwa pupuk organic ini akan menjadi solusi bagi para petani ditengah kelangkaan pupuk subsidi. Lebih lanjut diungkapkan bahwa beliau akan terus komitmen menggunakan pupuk ini untuk tanama jagungnya. Terbukti bahwa hingga saat ini, pemilik lahan demplot jagung manis ini sudah 3 kali melakukan penanaman jagung manis dan selalu menggunakan pupuk organic eco farming sebagai pupuk utamanya.

Dikatakan hasil panen jagung manis selalu mengalami peningkatan walaupun harga jual masih rendah dari sebelumnya. Lebih lanjut dikatakan bahwa luas lahan jagung 10 are dapat menghasilkan 8-9 kwintal per musim panen dengan biaya yang harus dikeluarkan untuk pupuk dan perawatan kurang lebih $\mathrm{Rp}$ 665.000. dengan rincian sebagai berikut: Benih 5 bks @ 250 gr x Rp $65.000=325,0000$. Marshall 1(untuk perlakuan benih) Rp 10.000 . Virtako Rp 25.000, Urea (subsidi) $20 \mathrm{~kg} \times 4,000$ $=$ Rp 80,000, eco farming $12 \mathrm{gr}=\mathrm{Rp} 100.000$ Racun rumput $\mathrm{Rp} 75.000 /$ bungkus, dan ongkos tanam Rp 50.000. Jika berpatokan dengan harga jual rata-rata $\mathrm{Rp} 2.500$ per kilogram, maka pendapatan kotor petani jagung manis ini untuk luas lahan 10 are dengan hasil 8 kwintal per musim sama dengan Rp 2.000.000. Setelah dikurangi biaya pupuk dan perawatan, maka keuntungan yang diperoleh petani jagung manis sebesar $\mathrm{Rp}$ 1.335.000. Hal ini berarti petani jagung manis ini dapat memperoleh keuntungan selama 4 kali panen setahun sebesar Rp 5.340.000. Hal ini yang menjadi pertimbangan kelompok tani jagung manis ini agar untuk dapat memperoleh keuntungan yang cepat dan lebih besar dibandingkan dengan menanam jagung pakan yang masa panen hingga 4 bulan atau harus menanam jenis tanaman lainnya. Selain itu, juga sebagai upaya membantu pemerintah untuk memenuhi kebutuhan jagung dari tahun ke tahun terus meningkat seiring dengan terus bertambahnya jumlah penduduk (Ratulangi et al., 2019).

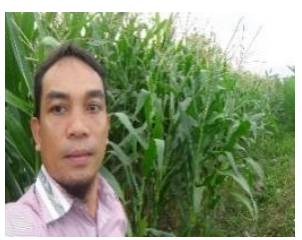

Gambar 9. Lahan Demplot jagung manis siap panen.

\section{SIMPULAN DAN SARAN}

Dari kegiatan pengabdian ini dapat disimpulkan bahwa terdapat peningkatan hasil panen jagung manis sekitar $20 \%$ dengan pengurangan Pukim hingga $80 \%$ dari biasanya pada tanaman jagung manis setelah musim tanam kedua sampai ke empat (4 kali musim tanam) dan meningkatkan keterampilan anggota kelompok tani Sinar Harapan dalam pengaplikasian Pupuk Organik Eco Farming dengan tanpa pendampingan.

\section{UCAPAN TERIMAKASIH}

Kami tim pengabdin masyarakat program studi pendidikan matematika mengucapkan terima kasih atas dukungan 
bantuan dana dan support dari LPPM UNDIKMA serta ucapan terima kasih kepada para petani yang terlibat dalam kegiatan pengabdian ini

\section{DAFTAR RUJUKAN}

Adiraputra, P., \& Supyandi, D. (2021). Efektivitas kebijakan subsidi pupuk di Desa Sukaasih Kecamatan Sukatani Kabupaten Bekasi. Mimbar Agribisnis: Jurnal Pemikiran Masyarakat IImiah Berwawasan Agribisnis, 7(1), 594-606. https://doi.org/10.25157/ma.v7i1.4745

Andriyani, D., Juliansyah, H., \& Sari, cut putri mellita. (2020). Jurnal Ekonomi Pertanian Unimal. Peningkatan Produktivitas Lahan Dan Pendapatan Petani Melalui Penggunaan Pupuk Organik Di Desa Blang Gurah Kecamatan Kuta Makmur Kabupaten Aceh Utara, 03(November), 17.

Handayani, W. A., Tedjaningsih, T., \& Rofatin, B. (2019). Peran kelompok tani dalam meningkatkan produktivitas usahatani padi. Jurnal AGRISTAN, 1(2), 80-88.

Iswahyudi, Budiyono, A., \& Wildani, A. (2019). Pendampingan penggunaan pupuk organik (eco farming) pada kelompok Tani Palem Desa Sumedangan Kabupaten Pamekasan. Seminar Nasional Hasil Pengabdian Kepada Masyarakat (SENIAS) 2019 - Universitas Islam Madura, 22-25. https://doi.org/10.33366/jast.v3i1.1273

Rahmawati, Baruwadi, M., \& Bahua, M. I. (2015). Peran kinerja penyuluh dan efektivitas pelaksanaan penyuluhan pada program intensifikasi jagung. JURNAL SOSIAL EKONOMI PERTANIAN, 15(1), 56-70.

Ratulangi, D. H. A., Katiandagho, T. M., \& Sagay, B. A. B. (2019). Faktor-faktor yang mempengaruhi keputusan petani menanam jagung manis dan jagung lokal. Agri-Sosioekonomi Unsrat, 15(3), 463472. 